\title{
Status Hukum Tanah Musnah Berdasarkan Permen ATR/BPN No. 17 Tahun 2021
}

\section{Bunga Desyana P., Rindiana Larasati, Sri Ratu RI, dan Iqbal Kamalludin}

Magister Kenotariatan Fakultas Hukum Universitas Islam Indonesia Yogyakarta Indonesia Jln. Cik Di Tiro No. 1 Yogyakarta Indonesia bunga.desyana.p@iainpekalongan.ac.id, larasati.ppat@gmail.com, tugas.kampus@yahoo.com, Iqbal.kamalludin@iainpekalongan.ac.id

\section{Key Word:}

Tidal flood, destroyed

land, legal status,

legal protection

\section{Abstract}

Everyone has the right to obtain recognition of guarantees, protection and fair legal treatment, and obtain legal certainty. The tidal flood disaster that occurred in Pekalongan City resulted in the land owners losing their right to control, use or take advantage of the land because the surface of the land and/or buildings erected on it was either partially or completely inundated by tidal water. This article aims to identify the legal status of pieces of land that are affected by tidal flood according to the Ministry of ATR/BPN Regulation Number 17 of 2021 of Procedures for Determination of Destroyed Land and to analyze the legal protections that can be obtained by owners of Land Rights on destroyed land as the result of a disaster. This is a normative juridical research with conceptual and statutory approaches by examining all the relevant laws and regulations. The results of this study conclude that the pieces of land affected by the tidal flood disaster in Pekalongan City has met the requirements to be considered as destroyed land based on the land requirements in Ministry of ATR/BPN Regulation Number 17 of 2021, the holders of the land are then given priority to carry out reconstruction or reclamation within a period of 1 (one) year, receive spiritual funds if the pieces of land is to be used and/or reconstruction or reclamation is carried out by the Government

\begin{abstract}
Abstrak
Setiap orang berhak memperoleh pengakuan jaminan, perlindungan dan perlakuan hukum seadil-adilnya, dan mendapatkan kepastian hukum. Bencana banjir rob yang terjadi di Kota Pekalongan mengakibatkan pemilik tanah kehilangan hak untuk menguasai, menggunakan atau mengambil manfaat atas tanah karena permukaan tanah dan/atau bangunan yang didirikan diatasnya baik sebagian atau seluruhnya tergenang oleh air rob. Artikel ini bertujuan untuk mengkaji dan menganalisis mengenai status hukum bidang tanah yang terkena banjir rob menurut Permen ATR/BPN Nomor 17 Tahun 2021 tentang Tata Cara Penetapan Tanah Musnah dan untuk mengkaji dan menganalisis mengenai perlindungan hukum yang bisa diperoleh Pemilik Hak Atas Tanah atas tanah yang musnah akibat bencana. Jenis Penelitian ini adalah penelitian yuridis normatif dengan pendekatan yang digunakan adalah pendekatan pendekatan konseptual dan pendekatan perundang-undangan dengan menelaah semua undang-undang dan regulasi. Hasil Penelitian ini menyimpulkan bahwa bidang tanah yang terdampak bencana banjir rob di Kota Pekalongan berdasarkan persyaratan tanah dapat di kategorikan sebagai musnah dalam Permen ATR/ BPN Nomor 17 Tahun 2021 telah memenuhi syarat dikatakan sebagai tanah musnah dan pemegang hak atas tanah diberikan prioritas untuk melaksanakan rekontruksi atau reklamasi dalam jangka waktu selama 1 (satu) tahun, mendapatkan dana kerohiman apabila bidang tanah tersebut akan digunakan dan/atau dilaksanakan rekontruksi atau reklamasi oleh Pemerintah.
\end{abstract}




\section{Pendahuluan}

Undang-Undang Dasar Negara Republik Indonesia Tahun 1945 mengamanatkan bahwa Pemerintah Negara Republik Indonesia wajib melindungi segenap bangsa dan seluruh tumpah darah Indonesia tercantum pada Pembukaan Alenia ke IV. Pembangunan nasional dilaksanakan sebagai implementasi dari amanat UndangUndang Dasar 1945 yang bertujuan untuk memberikan perhatian hak warga negara dan memberikan perrlindungan bagi seluruh bangsa Indonesia. Salah satu bagian dari pembagunan nasional adalah penanggulangan bencana sebelum terjadinya bencana, pada saat terjadi dan sesudah terjadinya bencana.

Negara Kesatuan Republik Indonesia sebuah Negara yang memiliki wilayah yang luas dan terletak di garis khatulistiwa berada diantara dua benua dan dua samudra menjadikan bangsa ini memiliki keunggulan karena letak goestrategis diantaranya Indonesia kaya akan sumber daya laut, namun pada kondisi ini juga menjadikan Indonesia rawan terhadap terjadinya bencana dengan frekuensi yang cukup tinggi.

Dalam Undang-Undang Nomor 24 Tahun 2007 tentang Penanggulangan Bencana, bencana diartikan sebagai berikut:

"Bencana merupakan peristiwa atau rangkaian peristiwa dan mengganggu kehidupan dan penghidupan masyarakat yang disebabkan, baik oleh faktor alam dan/atau faktor nonalam maupun faktor jiwa manusia, kerusakan lingkungan, kerugian harta benda dan dampak psikologis."1

Kategori bencana di Indonesia dikelompokkan menjadi 3, pertama, bencana alam yang merupakan serangkaian peristiwa yang disebabkan oleh alam berupa gempa bumi, tsunami, gunung meletus, banjir, abrasi, kekringan, angin topan dan tanah longsor. Kedua, bencana nonalam adalah bencana yang diakibatkan oleh peristiwa atau rangkaian peristiwa nonalam yang terjadi bukan disebabkan oleh gejala alam seperti epedemi, wabah penyakit, gagal tekhnologi dan gagal modernisasi. Ketiga, bencana sosial yang merupakan bencana yang diakibatkan oleh manusia yang meliputi konflik sosial antar kelompok atau antar komunitas masyarakat, terror, dan penyimpangan norma agama dan sosial. ${ }^{2}$

Setiap wilayah di Indonesia memiliki permasalahan yang beragam dalam hal potensi ancaman bencana baik secara alam maupun non alam, mulai dari kota besar hingga kota kecil maupun daerah pesisir hingga daratan tinggi. Wilayah pulau Jawa bagian utara dihadapkan dengan pontensi bencana banjir, abrasi, dan rob karena bagian utara Pulau Jawa bertopografi landai sehingga banjir dapat dengan mudah sampai kedaratan.

Kota Pekalongan terletak di wilayah utara pulau Jawa tepatnya di bagian utara Jawa Tengah dan termasuk dalam pesisir pantai utara. Sama halnya dengan daerah pesisir lainnya permasalahan yang dihadapi Kota Pekalongan berupa banjir rob yang

\footnotetext{
1 Pasal 1 Undang-Undang Nomor 24 Tahun 2007 tentang Penanggulangan Bencana.

2 Pasal 1 ayat (2), (3), dan (4) Undang-Undang Republik Indonesia Nomor 24 Tahun 2007 tentang Penanggulangan Bencana.
} 
menggenangi daratan baik yang bersifat sementara maupun yang sudah bertahun-tahun lamanya hal ini juga disebabkan dengan penurunan permukaan tanah. Berikut contoh kasus terkait penurunan tanah di Kota Pekalongan:

"KOMPAS.com - Hasil riset yang dilakukan Kepala Laboratorium Geodesi Institut Teknologi Bandung Heri Andreas dan tim menemukan bahwa ada 112 kota dan kabupaten di pesisir Indonesia yang mengalami penurunan muka tanah. Dari jumlah tersebut, yang terparah ada di Pekalongan. Kabupaten atau kota pesisir yang dimaksud Heri dalam studinya berada di pesisir utara Jawa, pesisir timur Sumatera, pesisir Kalimantan, sebagian pesisir Sulawesi, dan sebagian pesisir Papua. Nah, penurunan muka tanah di 112 kabupaten dan kota pesisir ini bervariasi kedalamannya, mulai dari 1-20 sentimeter per tahun. "Hingga saat ini, yang penurunan muka tanahnya paling tajam atau paling cepat lajunya ada di Pekalongan, Semarang, dan Demak. Baru kemudian Jakarta," ungkap Heri. Dalam hasil studinya, penurunan muka tanah di Pekalongan ada yang 15 sentimeter per tahun dan beberapa spot bahkan mencapai 20 sentimeter per tahun. ${ }^{3}$ “

Kondisi alam daratan Kota Pekalongan yang lebih rendah dari air laut menyebabkan bagian utara Kota Pekalongan terkena bencana rob yang abadi. Hal ini dipertegas dengan keterangan Badan Meteorologi, Klimatologi dan Geofisika (BMKG) mengeluarkan peringatan akan potensi banjir meluapnya air laut atau rob pada kawasan pesisir utara Pulau Jawa. ${ }^{4}$ Keadaan banjir rob yang bersifat tahunan ini menimbulkan beberapa permasalah dan kerugian yang dialami oleh warga yang terdampak bencana ini. Keadaan ini menjadikan berkurangnya tanah seiring dengan berjalannya waktu dengan adanya proses alam, tanah yang terkena banjir rob hilang secara alami karena tenggelam oleh air laut.

Sebagai contoh bencana banjir rob yang terjadi di Kota Pekalongan mengakibatkan pemilik tanah tidak dapat memanfaatkan tanahnya, menggunakan tanahnya sebagai tempat untuk hidup tumbuh berkembang di atas tanahnya. Bahkan pemilik hak atas tanah dapat kehilangan hak untuk menguasai, menggunakan atau mengambil manfaat atas tanah karena permukaan tanah dan/atau bangunan yang didirikan diatasnya baik sebagian atau seluruhnya tergenang oleh air rob, meskipun pemilik memiliki bukti hak atau sertifikat atas bidang tanah.

Pada Pasal 27 Undang-Undang Pokok Agraria Nomor 5 Tahun 1960 menyebutkan bahwa hak milik dapat hapus apabila tanahnya jatuh kepada Negara baik dikarenakan pencabutan, penyerahan secara sukarela, tanahnya ditelantarkan dan karena tanahnya musnah. Sebidang tanah dapat dikategorikan sebagai tanah musnah meliputi bidang tanah yang sudah berubah dari bentuk asalnya karena peristiwa alam, tidak dapat diidentifikasi lagi, dan tidak dapat difungsikan, digunakan dan dimanfaatkan

3 "Muka Tanah Pekalongan Turun Hingga 20 Cm Per Tahun, Ini Penyebab dan Dampaknya", https://www.kompas.com/sains/read/2021/09/17/173200423/muka-tanah-pekalongan-turun-hingga-20-cmper-tahun-ini-penyebab-dan., diakses pada tanggal 12 November 2021 pukul 22. 20 WIB.

4 "BMKG Peringatkan Potensi ROB Pesisir Utara Jawa pada 18-25 November 2021", $\underline{\text { BMKG }}$ Peringatkan Potensi Rob Pesisir Utara Jawa pada 18-25 November 2021 - News Liputan6.com, diakses pada tanggal 19 November 2021 pukul 16.45 WIB. 
sebagaimana mestinya. ${ }^{5}$ Hubungan antara manusia dengan tanah adalah hubungan yang bersifat abadi yang merupakan satu kesatuan dan tidak dapat dipisahkan dan dipisahkan satu dengan lainnya. ${ }^{6}$ Pada saat negara menghapus hubungan hukum ataran orang dengan tanahnya seyogyanya dilakukan secara patut melalui pranata perlindungan hukum yang jelas dan tegas, supaya kesejahteraan dan kemakmuran rakyat tercapai. Sesuai dengan hak asasi manusia yang tercantum dalam Pasal 3 ayat (2) Undang-Undang Nomor 39 Tahun 1999 tentang Kawasan Ekonomi Khusus menyatakan bahwa "Setiap orang berhak memperoleh pengakuan jaminan, perlindungan dan perlakuan hukum seadil-adilnya, mendapatkan perlakuan yang sama di depan hukum dan mendapatkan kepastian hukum".7

\section{Rumusan Masalah}

Berdasarkan pendahuluan yang penulis uaraikan, maka rumusan masalah yang diteliti adalah bagaimana status hukum bidang tanah yang terkena bencana banjir rob menurut Permen ATR/BPN No 17 Tahun 2021 tentang penetapan tanah musnah dan bagaimana perlindungan hukum yang bisa diperoleh Pemilik Hak Atas Tanah atas Tanah yang musnah.

\section{Tujuan Penelitian}

Tujuan penelitian merupakan saran atau target mengenai yang hendak dicapai dalam melaksanakan penelitain. Berdasarkan rumusan masalah yang telah diuraikan, penulisan ini bertujuan untuk mengkaji dan menganalisis mengenai status hukum bidang tanah yang terkena banjir rob menurut Permen ATR/BPN Nomor 17 Tahun 2021 tentang Tata Cara Penetapan Tanah Musnah dan perlindungan hukum yang bisa diperoleh Pemilik Hak Atas Tanah atas tanah yang musnah akibat bencana.

\section{Metode Penelitian}

Jenis penelitian yang digunakan dalam penelitian ini adalah penelitian yuridis normatif yang menelaah hukum dari perspektif internal dengan objek penelitiannya adalah norma hukum. Penelitian normatif berfungsi untuk memberikan argumentasi yuridis ketika terjadi kekosongan, kekaburan dan konflik norma. ${ }^{8}$ Metode pendekatan yang digunakan adalah pendekatan konseptual dan pendekatan perundang-undangan dengan menelaah semua undang-undang dan regulasi yang bersangkutan dengan masalah hukum yang dibahas penulis. Bahan hukum yang diperoleh dari hasil penelitian

5 Pasal 2 ayat (2) Peraturan Menteri ATR/Kepala BPN Republik Indonesia Nomor 17 Tahun 2021 tentang tata cara Penetapan Tanah Musnah

${ }^{6}$ M. Arba, Hukum Pengadaan Tanah Untuk Kepentingan Umum, Cetakan Pertama, Sinar Grafika, Jakarta, 2019, hlm. 1.

${ }^{7}$ Dwi Susiati, Sri Setiadji, "Status Hukum Hak Milik Atas Tanah Yang Terkena Abrasi”, Mimbar Keadilan Vol. 13 No. 1, Februari 2020 - Juli 2020, hlm. 98.

8 I Made Pasek Diantha, Metodelogi Penelitian Hukum Normatif Dalam Justifikasi Teori Hukum, Cetakan Kedua, Kencana, Jakarta, 2017, hlm. 12. 
kepustakaan dianalisis secara deskriptif kualitatif, yaitu mengumpulkan dan menyeleksi bahan hukum sesuai dengan permasalahan yang teliti, kemudian dideskripsikan sehingga menghasilkan gambaran atau kesimpulan yang sesuai dengan keadaan sebenarnya sehingga mampu menjawab permasalahan yang dikaji. Cara pengumpulan bahan hukum dilakukan dengan cara studi pustaka, yaitu dilakukan dengan mengkaji buku, jurnal, undang-undang yang berkaitan dengan permasalahan yang dikaji.

\section{Hasil Penelitian dan Pembahasan}

\section{Status Hukum Bidang Tanah yang Terkena Bencana Banjir Rob Menurut Permen ATR/BPN No 17 Tahun 2021 tentang Tata Cara Penetapan Tanah Musnah}

Seluruh wilayah Indonesia adalah kesatuan tanah air dari seluruh rakyat Indonesia, yang bersatu sebagai Bangsa Indonesia; Hubungan hukum antara Bangsa Indonesia dan bumi, air, dan ruang angkasa adalah hubungan yang abadi. ${ }^{9}$

Hak Bangsa Indonesia mengandung 2 unsur, yaitu unsur kepunyaan dan unsur tugas. Kewenangan untuk mengatur dan memimpin penguasaan dan penggunaan tanah bersama yang dipunyainya. Hak Bangsa atas tanah bersama dalam rangka Hak Bangsa ada Hak Milik perorangan atas tanah. Tugas kewenangan untuk mengatur penguasaan dan memimpin penggunaan tanah bersama tersebut pelaksanaanya dillimpahkan kepada negara. ${ }^{10}$

Dalam pelaksanaannya wewenang yang diberikan kepada negara dapat dilimpahkan kepada Pemerintah Daerah dan masyarakat hukum adat, sepanjang hal itu diperlukan dan tidak bertentangan dengan kepentingan nasional, sebagai tugas pembantuan, bukan otonomi. Pada hakikatnya wewenang tersebut terbatas dalam hal wewenang mengatur bersangkutan dengan perencanaan pembangunan daerah dan menyelenggarakan penruntukan, penggunaan, persediaaan dan pemeliharaan tanah berupa tindakan mematangkan tanah yang tersedia dan mengatur penyediaan tanah bagi pihak yang memerlukan.11

Selain kewenangan, hak atas tanah juga berisikan kewajiban untuk menggunakan dan memelihara potensi tanah. Dalam UUPA kewajiban yang berdifat umum berlaku bagi setiap hak atas tanah diatur dalam: ${ }^{12}$

1. Pasal 6 yang menyatakan bahwa semua hak atas tanah mempunyai fungsi sosial. Dapat diartikan bahwa setiap hak atas tanah yang melekat pada bidang tanah tidak dibenarkan bahwa tanah itu digunakan semata-mata untuk kepentingan pribadinya saja, bahkan tidak dibenarkan jika merugikan orang lain;

2. Pasal 15 dihubungakan dengan Pasal 52 ayat (1) tentang kewajiban pemeganag hak atas tanah untuk memelihara tanah;

\footnotetext{
${ }_{9}$ Pasal 1 ayat (1) dan (3) UUPA.

10 Boedi Harsono, Hukum Agraria Indonesia Sejarah Pembentukan Undang-Undang Pokok Agraria, Isi dan Pelaksanaannya Jilid 1 Hukum Tanah Nasional, Cetakan keduabelas, Djambatan, Jakarta, 2008, hlm. 266.

11 Ibid., hlm. 275.

12 Ibid., hlm. 296
} 
3. Pasal 10 khusus mengenai tanah pertanian, yaitu kewajiban bagi pihak yang mempunyai tanah pertanian untuk mengerjakan atau mengusahakan atau menggunakan dan memanfaatkan tanah itu secara aktif.

Dalam pemanfaatan tanah pada sebagian daerah mengalami kondisi alam yang tidak memungkinkan untuk melaksanakan kewajiban atas sebidang tanahnya. Seperti halnya yang penulis telah sampaikan pada pembahasan sebelumnya bahwa pada Kota Pekalongan Utara wilayah yang terdampak banjir rob dimana keadaan bidang tanah tersebut telah tenggelam oleh air laut yang telah bertahun-tahun bahkan bangunan yang berdiri diatasnya telah terkikis oleh air laut sehingga ditinggalkan oleh sang pemilik. Hal ini sangat menjadi luka bagi pemegang hak atas tanah, dikarenakan mereka memiliki sertifikat atau alas hak atas bidang tanah tersebut namun tidak dapat memanfaatkannya. Selama ini bidang tanah tersebut di diamkan saja tanpa ada tindakan dan perhatian dari pemerintah setempat.

Adanya Peraturan Menteri Agraria dan Tata Ruang/Kepala Badan Pertanahan Nasional Republik Indonesia Nomor 17 Tahun 2021 tentang Tata Cara Penetapan Tanah Musnah, diharapkan dapat menjadi jawaban untuk kepastian status tanah yang telah tenggelam karena air rob.

Pasal 2 Permen ATR/KBPN Nomor 17 Tahun 2021 tersebut menegaskan bahwa hak pegelolaan dan/atau hak atas tanah hapus karena tanahnya musnah. Sebidang tanah dikatakan musnah jika memenuhi beberapa kriteria yaitu:

a. Sudah berubah dari bentuk asalanya karena peristiwa alam;

b. tidak dapat diidentifikasi lagi; dan

c. tidak dapat difungsikan, digunakan dan dimanfaatkan sebagaimana mestinya. ${ }^{13}$

Dari kriteria di atas dengan melihat kondisi bidang tanah yang ada di Kota Pekalongan bagian Utara yang terkena banjir rob sudah memenuhi semua kriteria tanah musnah. Karena, bidang tanah sudah tidak berujud daratan, bangunan telah tenggelam lebih dari setenggah dan sudah ditinggalkan oleh pemegang hak dikarenakan sudah tidak dapat dimanfaatkan lagi keberadaannya.

Suatu bidang tanah ditetapkan kedalam kategori tanah musnah, berdasarkan Permen ATR/KBPN Nomor 17 Tahun 2021 ada beberapa tahapan yaitu: penetapan lokasi; pembentukan tim peneliti tanah musnah; sosialisasi; identifikasi, investarisasi dan pengkajian; pengumuman; pelaksanaan rekontruksi ${ }^{14}$ atau reklamasi apabila pemilik tanah menyatakan akan melaksanakan rekontruksi dan/atau reklamasi dan/atau penerbitan keputusan penetapan tanah musnah. ${ }^{15}$

${ }^{13}$ Pasal 2 Permen ATR/KBPN Nomor 17 Tahun 2021 tentang Tata Cara Penetapan Tanah Musnah.

14 Rekontrusi adalah pembangunan kembali semua prasarana dan sarana, kelembagaan pada wilayah pascabencana, baik pada tingkat pemerintahan maupun masyarakat dengan sasaran utama tumbuh dan berkembangnya kegiatan perekonomian, sosial dan budaya, tegaknya hukum dan ketertiban, dan bangkitnya peran serta masyarakat dalam segala aspek kehidupan bermasyarakat pada wilayah pascabencana. Pasal 1 ayat (12) Undang-Undang Nomor 24 Tahun 2007 tentang Penganggulangan Bencana.

15 Pasal 3 Permen ATR/KBPN Nomor 17 Tahun 2021 tentang Tata Cara Penetapan Tanah Musnah. 
Pada tahap penetapan lokasi, Kepala Kantor Badan Pertanahan menetapkan lokasi bidang tanah yang terindikasi sebagai tanah musnah berdasarkan hasil kegiatan pemantauan dan evaluasi atau informasi pemberitahuan dari instansi pusat, daerah maupun masyarakat atau pihak lain. Dalam penetapan lokasi dilengkapi dengan peta lokasi dan data awal atas bidang tanah yang terindikasi sebagai tanah musnah dengan memuat setidaknya nama pemegang hak, jenis dan nomor hak, nomor surat ukur, nomor identifikasi bidang tanah, desa/kelurahan, kecamatan letak tanah, luas tanah, penggunaan/pemanfaatan tanah, dan/atau catatan pendaftaran atau catatan lainnya. Pelaksanaan tugas tim peneliti tanah musnah paling lama 90 hari sejak tanggal Keputusan Pembentukan Tim Peneliti Tanah Musnah. ${ }^{16}$

Kegiatan sosialisasi dilaksanakan paling sedikit 1 kali di kantor desa/kelurahan letak tanah atau tempat yang ditentukan. Dilanjutkan dengan identifikasi dan inventarisasi atas bidang tanah yang meliputi jenis hak, alat bukti tertulis kepemilikan tanah berupa sertifikat atau alas hak lainnya, pemilikan tanah, pemanfaatan tanah, keadaan tanah saait ini, luas tanah yang terindikasi sebagai tanah musnah, dan batas bidang tanah. Kemudian dilanjutkan dengan risalah Tim Peneliti Tanah Musnah dengan memuat dasar hukum atas hapusnya hap pengelolaan dan/atau Hak Atas Tanah, uraian atas hak yang akan ditetapkan sebagai tanah musnah, uraian atas data pendukung tanah musnah, pengkajian atas tanah musnah, kesimpulan dan rekomendasi bidang tanah yang ditetapkan sebagai tanah musnah baik sebgaian atau seluruhnya. ${ }^{17}$

Bidang tanah sudah ditetapkan sebagai tanah musnah, maka Kepala Kantor Pertanahan mengumumkan bidang tanah yang akan ditetapkan sebagai tanah musnah secara tertulis dan terbuka pada kantor desa/kelurahan dan kantor pertanahan atau website kementerian selama 14 hari kalender untuk memberikan prioritas bagi pemegang hak atas tanah untuk melaksanakan rekontruksi atau reklamasi. Selama masa pengumuman pemegang hak tidak membuat surat pernyataan untuk melakasanakan rekontruksi atau reklamasi maka dianggap tidak berkenan dan menyetujui bidang tanah tersebut ditetapkan sebagai tanah musnah. Namun, apabila pemegang hak berkenan melakukan rekontruksi ataupun reklamasi maka diberikan jangka waktu selama 1 tahun untuk melaksanakannya. ${ }^{18}$

\section{Perlindungan Hukum yang Diperoleh Pemilik Hak atas Tanah terhadap Bidang Tanah yang Ditetapkan sebagai Tanah Musnah Akibat Banjir Rob}

Bencana banjir rob yang terjadi di beberapa daerah, contohnya Kota Pekalongan bagian utara menenggelamkan bidang tanah dan sebagian bangunan yang berdiri diatas hak atas tanah. Dikutip dari pendapat ahli hukum agraria Maria SW Sumardjono, tidak berarti korban bencana telah kehilangan hak milik atas tanah yang sebelum bencana menjadi milik mereka. Dalam Undang-Undang Nomor 5 Tahun 1960 tidak mengenal

16 Pasal 4 dan Pasal 6 ayat (2) Permen ATR/KBPN Nomor 17 Tahun 2021 tentang Tata Cara Penetapan Tanah Musnah.

17 Pasal 8 dan Pasal 10 Permen ATR/KBPN Nomor 17 Tahun 2021 tentang Tata Cara Penetapan Tanah Musnah.

18 Pasal 12, Pasal 14 Permen ATR/KBPN Nomor 17 Tahun 2021 tentang Tata Cara Penetapan Tanah Musnah. 
penghapusan hak milik atas tanah dikarenakan terjadinya bencana alam. Kecuali bidang tanah tersebut tidak musnah, masih terdapat cara yang mungkin diupayakan. ${ }^{19}$

Meskipun dalam UUPA tidak menyebutkan secara terang bahwa hak atas tanah hapus karena bencana alam, namun UUPA menjelaskan bahwa hak atas tanah dapat hapus karena hal-hal sebagaimana disebut dalam Undang-Undang Nomor 5 Tahun 1960 tentang Ketentuan-Ketentuan Pokok Agraria, Pasal 27 menyebutkan bahwa Hak Milik hapus apabila tanahnya jatuh kepada Negara dan tanahnya musnah, Pasal 34 menyatakan bahwa Hak Guna Usaha hapus apabila jangka waktunya berakhir, dihentikan sebelum jangka waktunya berakhir karena sesuatu syarat tidak terpenuhi, dilepaskan oleh pemegang haknya sebelum jangka waktunya berakhir, diccabut untuk kepentingan umum, ditelantarkan dan tanahnya musnah. Sedangkan dalam Pasal 40 menjelaskan bahwa Hak Guna Bangunan hapus karena jangka waktunya berakhir, dihentikan sebelum jangka waktunya berakhir karena sesuatu syarat tidak terpenuhi, dilepaskan oleh pemegang haknya sebelum jangka waktunya berakhir, dicabut untuk kepentingan umum, ditelantarkan dan tanahnya musnah.20

Peraturan perundang-undangan lainnya yang mengatur tentang hal-hal yang dapat mengakibatkan hapusnya hak atas tanah terdapat dalam Pasal 66 PP Nomor 18 tahun 2021 menegaskan bahwa bidang tanah yang tidak dapat diidentifikasi lagi karena sudah berubah dari bentuk asalnya karena peristiwa alam sehingga tidak dapat difungsikan, digunakan, dan dimanfaatkan sebagaimana mestinya, dinyatakan sebagai Tanah Musnah dan Hak Pengelolaan dan/atau Hak Atas Tanah dinyatakan hapus. ${ }^{21}$ Kata "HAPUS" mengerucut pada Hak Atas Tanah yang melekat pada bidang tanah yang telah dikatakan musnah, dalam hal ini dapat diartikan bahwa pemegang hak atas tanah tersebut telah kehilangan haknya atas bidang tanah meskipun pemilik bidang tanah mempunyai bukti kepemilikan.

Hapusnya hak atas tanah yang terkena bencana rob yang merupakan termasuk dalam bencana alam, seperti yang sudah dijelaskan di atas bahwa status hukum tanah yang terkena bencana hapus karena tanahnya musnah, tetapi tidak menutup kenyataan bahwa ada pihak yang dirugikan dengan hapusnya hak atas tanah tersebut dan pemerintah secara implisit dalam perundang-undangan ikut bertanggung jawab atas kesejahteraan rakyat, berkewajiban memberikan jaminan atas tanah yang musnah tersebut. Dalam Pasal 28 D dan Pasal 33 ayat (3) Undang-Undang Dasar 1945 menjadi dasar jaminan dan perlindungan atas tanah-tanah tersebut sebagai bentuk perlindungan dari pemerintah.22 Dari Pasal 33 ayat (3) UUD 1945 menurunkan penjabaranya kepada Pasal 2 UUPA menjelaskan bahwa negara menjadi organisasi tertinggi dalam mengusai bumi, air, dan ruang angkasa termsuk kekayaan alam yang terkandung didalamnya dan Pasal 14 UUPA dijelaskan bahwa negara memberikan mandat kepada Pemerintah

19 Bagus Rahmanda, "Perlindungan Hukum Bagi Pengusaha Pemilik Tanah Akibat Musnahnya Tanah Akibat Bencana Alam Dan Kaitannya Dengan Pihak Ketiga", Gema Keadilan Vol. 6 Edisi 1, Juni 2019, hlm. 68.

${ }^{20}$ Undang-Undang Nomor 5 Tahun 1960 tentang Ketentuan-Ketentuan Pokok Agraria.

21 Peraturan Pemerintah Republik Indonesia Nomor 18 Tahun 2021 tentang Hak Pengelolaan, Hak Atas Tanah, Satuan Rumah Susun dan Pendaftaran Tanah.

22 Dwi Susiati, Sri Setiadji, "Status Hukum....", Op. Cit., hlm. 105. 
Daerah untuk mengatur persediaan, peruntukkan dan penggunaan Bumi, Air dan Ruang angkasa untuk daerahnya. ${ }^{23}$ Jika dipahami dari penjelasan di atas penulis mengartikan bahwa negara dan Pemerintah Daerah berwewenang untuk mengelola daerahnya. Sebelumnya terjadinya bencana banjir rob yang memusnahkan tanah warga di Kota Pekalongan harusnya dapat di prediksi untuk mengantisipasi adanya bencana rob tersebut.

Pada 2021, sebagai bentuk pelaksanaan ketentuan Pasal 66 PP Nomor 18 Tahun 2021, Kementerian Agraria dan Tata Ruang / Kepala Bapan Pertanahan Nasional menetapkan Peraturan Menteri Nomot 17 Tahun 2021 tentang Tata Cara Penetapan Tanah Musnah. Dalam Permen tersebut diharapkan menjadi solusi dan perlindungan hukum dari permasalahan yang terjadi di beberapa wilayah Indonesia yang rawan akan bencana alam yang mengakibatkan musnahnya bidang tanah salah satunya seperti abrasi dan rob tahunan yang terjadi ke Kota Pekalongan.

Dalam penjelasan sebelumnya penulis telah memberikan contoh bahwa bencana rob yang terjadi di Kota Pekalongan termasuk dalam kategori tanah musnah berdasarkan Permen tentang Tata Cara Penetapan Tanah Musnah. Dalam hal kepastian hukum yang dapat diperjuangkan untuk pemegang hak atas tanah yang kehilangan hak atas tanahnya tersebut dalam Permen ini menyatakan bahwa pemegang hak pengelolaan dan/atau hak atas tanah diberikan prioritas wewenang untuk melaksanakan rekontruksi atau reklamasi terhadap bidang tanah yang terdampak bencana dengan membuat surat pernyataan dan diberikan waktu untuk melaksanakan rekontruksi atau reklamasi diberikan dalam jangka waktu 1 tahun. Apabila dalam jangka waktu yang telah ditetapkan tidak melakukan rekontruksi ataupun reklamasi maka tanah tersebut ditetapkan sebagai tanah musnah.

Dalam Pasal 15 dijelaskan bahwa dalam hal bidang tanah akan digunakan dan/atau akan dilakukan rekontruksi atau reklamasi oleh Pemerintah Pusat/Pemerintah Daerah atau pihak lain dalam rangka pembangunan untuk kepentingan umum, maka pemegang hak pengeolaan dan/atau hak atas tanah tidak diberikan prioritas untuk melaksanakan rekontruksi atau reklamasi dan bidang tanah ditetapkan sebagai tanah musnah. Pada ayat (2) menjelaskan bahwa pemegang hak pengelolaan dan/atau hak atas tanah diberikan bantuan dana kerohiman apabila bidang tanah tersebut akan digunakan dan/atau dilaksanakan rekontruksi atau reklamasi oleh Pemerintah Pusat ataupun Pemerintah Daerah. ${ }^{24}$

Perlu digarisbawahi bahwa Permen ini hanya memberikan dana kerohiman kepada pemegang hak pengelolaan atau hak atas tanah yang bidang tanahnya ambil alih oleh Pemerintah Pusat maupun Pemerintah Daerah. Jika bidang tanah tersebut ditetapkan sebagai tanah musnah maka pemegang hak pengelolaan atau hak atas tanah tidak mendapatkan ganti rugi. Dalam Permendagri Nomor 15 Tahun 1975 menyebutkan bahwa untuk menetapkan ganti kerugian harus memperhatikan paling tidak dua aspek:25

${ }^{23}$ Undang-Undang Nomor 5 Tahun 1960 tentang Ketentuan-Ketentuan Pokok Agraria.

${ }_{24}$ Peraturan Menteri Agraria dan Tata Ruang/ Kepala Badan Pertanahan Nasional Republik Indonesia Nomor 17 Tahun 2021 tentang Tata Cara Penetapan Tanah Musnah.

25 Maria, S.W. Sumardjono, Tanah Dalam Perspektif Hak Ekonomi Sosial dan Budaya, Cetakan Kedua, Kompas, Jakarta, 2009, hlm. 250. 
1. Penetapannya harus didasarkan atas musyawarah antara Panitia dengan para pemegang hak atas tanah;

2. Penetapannya harus memperhatikan harga umum setempat, di samping faktor lain yang mempengaruhi harga tanah.

Namun penetapan ganti rugi ini hanya dapat diterapkan apabila bidang tanah tersebut diambil untuk kepentingan umum, bukan ditetapkan sebagai tanah musnah.

Dalam Undang-undang Penanggulanggan Bencana Nomor 24 Tahun 2007 menyebutkan bahwa Pemerintah dan Pemerintah Daerah menjadi penanggung jawab dalam penyelenggaraan penanggulangan bencana. Penanggulangan yang diberikan bisa meliputi: pengurangan risiko bencana dan pengurangan risiko bencana dengan program pembangunan, pemulihan kondisi, dan penjaminan pemenuhan hak masyarakat dan pengungsi yang terkena bencana secara adii dan sesuai dengan standar pelayanan minimum. ${ }^{26}$ Perlu dicermati di sini, apakah bencana rob yang terjadi di Kota Pekalongan ini masuk dalam kategori bencana nasional berdasarkan Undang-Undang Nomor 24 Tahun 2007 tentang Penanggulangan Bencana.

\section{Penutup}

Bidang tanah yang terdampak bencana banjir rob di Kota Pekalongan jika berdasarkan persyaratan tanah dapat di kategorikan sebagai musnah dalam Permen ATR/ BPN Nomor 17 tahun 2021 telah memenuhi syarat dikatakan sebagai tanah musnah, karena bidang tanah sudah tidak berujud daratan, bangunan telah tenggelam lebih dari setenggah sehingga tanah tidak dapat terindentifikasi dan sudah ditinggalkan oleh pemegang hak dikarenakan kondisi tanah dan bangunan sudah tidak dapat dimanfaatkan lagi keberadaannya. Sesuai dengan Pasal 2 Permen tersebut yang menyatakan bahwa tanah musnah ialah sudah berubah dari bentuk asalanya karena peristiwa alam; tidak dapat diidentifikasi lagi; dan tidak dapat difungsikan, digunakan dan dimanfaatkan sebagaimana mestinya. Dengan demikian, perlunya tindakan dari Pemerintah Pusat maupun Pemerintah Daerah untuk menindaklajuti adanya Permen ATR / BPN Nomor 17 Tahun 2021 untuk memberikan kepastian hukum status bidang tanah yang terkena dampak banjir rob tahunan di Kota Pekalongan.

Adanya kepastian hukum mengenai status tanah melalui penetapan bidang tanah yang terdampak banjir rob di Kota Pekalongan dapat dikatakan sebagai tanah musnah atau tidak, maka dapat memberikan kepastian hukum juga kepada pemegang hak atas tanah yang bersangkutan. Permen ATR/BPN mengenai Tata Cara Penetapan Tanah Musnah, jika suatu bidang tanah dikategorikan sebagai tanah musnah maka mengikutsertakan hapusnya hak atas tanah tersebut. Hal ini dipertegas dalam Pasal 27 UUPA bahwa hak atas tanah hapus jika bidang tanah tersebut musnah, tanah yang ditetapkan tanah musnah. Dengan adanya Permen ATR / BPN Nomor 17 Tahun 2021 tentang Tata Cara Penetapan Tanah Musnah memberikan perlindungan dan kepastian

\footnotetext{
26 Pasal 5 dana Pasal 6 Undang-Undang Nomor 24 Tahun 2007 tentang Penanggulangan Bencana
} 
hukum kepada pemegang hak atas tanah yang tanahnya masuk sebagai kategori tanah musnah berupa:

1. Memberikan prioritas bagi pemegang hak atas tanah untuk melaksanakan rekontruksi atau reklamasi dalam jangka waktu selama 1 (satu) tahun untuk melaksanakannya.

2. Mendapatkan dana kerohiman apabila bidang tanah tersebut akan digunakan dan/atau dilaksanakan rekontruksi atau reklamasi oleh Pemerintah Pusat ataupun Pemerintah Daerah.

3. Jika pemegang hak atas tanah tidak berkenan melaksanakan rekontruksi ataupun reklamasi maka tanah tersebut ditetapkan sebagai tanah musnah dengan Penerbitan Keputusan Penetapan Tanah Musnah oleh Kantor Pertanahan setempat.

Dalam menjamin hapusnya hak tanah karena tanahnya musnah akibat bencana alam, pemerintah sepatutnya menjadi penganggung jawab berdasarkan Pasal 5 UndangUndang penanggulangan bencana yang menyebutkan bahwa pemerintah baik pusat maupun daerah sebagai penanggung jawab dalam menangulangi bencana dan dalam Pasal 6 juga menyebutkan bentuk tanggung jawab pemerintah dalam penyelengaraan penanggulangan salah satunya dengan memberikan perlindungan kepada masyarakat yang terdampak bencana.

Pemerintah Daerah Kota Pekalongan segera mungkin bisa menindak lanjuti Permen ATR/ BPN Nomor 17 Tahun 2021 dan mempertimbangkan Undang-Undang Penanggulangan Bencana untuk memberikan kepastian dan perlindungan hukum kepada masyarakat Kota Pekalongan yang terdampak banjir rob. Diharapkan Pemerintah dapat memperhatikan warga yang masih tinggal di bibir pantai yang lokasinya selalu terndam air banjir rob.

\section{Daftar Pustaka}

\section{Buku}

Arba, M., Hukum Pengadaan Tanah Untuk Kepentingan Umum, Cetakan Pertama, Sinar Grafika, Jakarta, 2019.

Diantha, I Made Pasek, Metodelogi Penelitian Hukum Normatif Dalam Justifikasi Teori Hukum, Cetakan Kedua, Kencana, Jakarta, 2017.

Harsono, Boedi, Hukum Agraria Indonesia Sejarah Pembentukan Undang-Undang Pokok Agraria, Isi dan Pelaksanaannya Jilid 1 Hukum Tanah Nasional, Cetakan keduabelas, Djambatan, Jakarta, 2008.

Sumardjono, Maria, S.W., Tanah Dalam Perspektif Hak Ekonomi Sosial dan Budaya, Cetakan Kedua, Kompas, Jakarta, 2009

\section{Jurnal}

Bagus Rahmanda, "Perlindungan Hukum Bagi Pengusaha Pemilik Tanah Akibat Musnahnya Tanah Akibat Bencana Alam Dan Kaitannya Dengan Pihak Ketiga", Gema Keadilan Vol. 6 Edisi 1, Juni 2019

Dwi Susiati, Sri Setiadji, "Status Hukum Hak Milik Atas Tanah Yang Terkena Abrasi", Mimbar Keadilan Vol. 13 No. 1, Februari 2020 - Juli 2020. 
Bunga DP., Rindiana L., Sri Ratu RI., dan Iqbal K. Status Hukum Tanah Musnah... 229

\section{Internet}

"Muka Tanah Pekalongan Turun Hingga $20 \mathrm{Cm}$ Per Tahun, Ini Penyebab dan Dampaknya", https://www.kompas.com. diakses 12 November 2021.

"BMKG Peringatkan Potensi ROB Pesisir Utara Jawa pada 18-25 November 2021", http:/ /News.Liputan6.com. , diakses pada 19 Noveember 2021

\section{Peraturan Perundang-Undangan}

Undang-Undang Nomor 24 Tahun 2007 tentang Penanggulangan Bencana

Undang-Undang Nomor 5 Tahun 1960 tentang Peraturan Dasar Pokok-Pokok Agraria

Peraturan Pemerintah Republik Indonesia Nomor 18 Tahun 2021 tentang Hak Pengelolaan, Hak Atas Tanah, Satuan Rumah Susun dan Pendaftaran Tanah

Peraturan Menteri Agararia dan Tata Ruang / Kepala Badan Pertanahan Nasional Republik Indonesia Nomor 17 Tahun 2021 tentang Tata Cara Penetapan Tanah Musnah 